\title{
Competing Norms and European Private International Law
}

\section{Dr. Ervis Çela}

Faculty of Law, University of Tirana, Albania

Mnd. Radovan Çela

Tirana Municipality, Albania

\section{Doi:10.5901/ajis.2014.v3n2p133}

This article takes into account recent developments in private international law. It focuses on finding either the "regulatory" or "liberalizing" role of PIL rules if one has to do with "competing norms". The central question here is whether there is a need for a central European regulator in the regulation of PIL issues: to what extent does central European regulation of PIL issues creates either opportunities or risks, in the sense that States will be tempted to learn from each other either in a positive, or in a negative way? Should regulation of PIL issues at European level be welcomed, if one wants to avoid the "risks of unregulated competition" and if one wants to increase the level of human rights protection within the Union? In an attempt to answer this question, the article analyzes - seen from this perspective - the manner in which European authorities intervened in PIL so far, and discusses current developments and possible future actions. The analysis of the European interference in PIL in the article includes both the promulgation of pure PIL-rules at European level, as the European regulation of PIL-issues which occasionally occur in regulating other areas of law, as the control of national PIL-legislation by the European Court of Justice. To that end, I examine a number of case studies, in which either "Europe" regulated PIL issues, or the settlement of PIL issues were left to the Member States: international labour law; international tort law; international family law, including international family law in interaction with other branches of law; international company law; international contract law. The conclusion is that European interference in PIL shows a "double face". The potential for European regulation of PIL issues in terms of promoting human rights and stimulating. Member States to implement "the best law" is high and attractive. But at the same time, it is important to be warned against creating dynamics of race to the bottom and reduction of the level of protection of weaker parties, precisely as a result of European interference in PIL issues. Consciousness of these opportunities and risks is necessary if one is discussing ways of avoiding unregulated competition and ways of encouraging the exchange of best practices.

This contribution deals with the relevance of the discipline of private international law (PIL) as a means of promoting human rights in the European Union (EU). The search for ways of promoting human rights in the EU sparks off debates on issues such as regulatory competition and collective learning, and PIL may be relevant to these debates. In this context, I focused attention mainly on aspects of tort law, contract law, labour law and family law in international legal relationships. I have used some of these sub disciplines of PIL as case studies. For example, I pointed out the extent to which these branches of law are affected by Europeanization of PIL and discussed the question to what extent the European legislator gives substance to this development and the scope for policy-making to be left to the Member States; for example, I pinpointed the impact of Europeanization of PIL at the level of human rights protection - and, in a broader sense, protection of parties that are traditionally considered weaker parties in law - maintained in the EU. In the end, I attempted to define, in a fragmentary manner, the convergence or tension between old and new European trends to instrumentalise PIL, and their interaction with the promotion of human rights.

Naturally, in discussing these case studies, I will identify developments that have occurred after I finished the previous article - for example, the publication of the final version of the Services Directive and the Rome II Regulation, recent court decisions in the field of international labour law, a recently published opinion rendered in the Grunkin-Paul case etc. These developments show that more and more is being regulated at European level - and I will describe the manner in which this has happened and the choices that have been made - but that at the same time, the European legislator has deliberately refrained from adopting further European rules in some cases and has left the body of national or already existing European PIL intact - e.g. the regulation of PIL aspects concerning defamation, even if regulation in this area has been postponed and may be addressed at a later stage (L. de Lima Pinheiro, 2008, p. 206-213); see also, for example, the exclusion of the regulation of international labour law aspects from the Services Directive. I will highlight 
these and other developments and in that sense.

As for recent publications, M. Watts, Guest Editorial published on the weblog www.conflictoflaws.net (2008) several reference points. The Guest Editorial was published under the title Reshaping Private International Law in a Changing World. In her Guest Editorial, M.Watt (2003 Vol.7/3) putted her finger on the problems concerned and, where she talks about the need for or the role of a central regulator for the regulation of PIL, she addressed the heart of the central question in this contribution. In it, M. Watt postulated, inter alia, in the absence of a central authority, the extent to which public interest concerns interfere with party choice is left to the unilateral decision of each state, in which context she identifies risks of under or over-regulation. M.Watt wrote about the requirements of collective welfare within the internal market. The creation of a central regulator that is permitted to regulate PIL aspects in some way or another is not self-evident: one of the essential features of the discipline of PIL is that PIL is in essence a national branch of law.

Traditionally, national PIL rules have included defense mechanisms that allow the relevant country's authorities to put a check on unlimited forum shopping and law shopping's between legal systems - for example, by invoking the plea of international public order or by applying specific rules that qualify as mandatory rules (or internationally mandatory rules) in the forum. But at the same time, it is these very PIL rules, whether of national or supranational origin, that permit one or both parties to a greater or lesser extent to take advantage of differences in legislation between countries - for example, because the PIL rules include flexible recognition and enforcement conditions or because applicable law rules offer a wide range of choice of law options. PIL rules themselves sometimes create the possibility of gaining an advantage from foreign law or avoiding the law applicable in the forum - for example, by permitting forum shopping to a certain extent, by offering choice of law options, by not remedying a foreign court's disregard of the internationally mandatory rules applicable in the forum in the phase of recognition of this foreign court's decision. In a similar vein, I addressed the concepts of availability and transferability in a PIL context before.

In the legal literature there are debates on whether offering such shopping options to parties ultimately results in the best law automatically emerging as it were. Does this ultimately lead to the creation of race-to-the-bottom or race-tothe-top dynamics, as the question is often formulated as well. This discussion is reflected, inter alia, in a recent contribution by L. Pinheiro in Competition between Legal Systems in the EU and Private International Law (2008. P. 206213). It contains the warning that in an area such as international company law, the shopping option may be at the expense of the protection of legitimate third-party interests. R. Wai (p. 254), where he talked about a "basic concern": "Regulatory competition in an international system where private actors are able to move from jurisdiction to jurisdiction in order to find the most favorable regulatory climate. In this situation, not only will private actors slip through the "gaps" of a fragmented regulatory regime, but through actual movement abroad, or threats of such movement, economic producers may also generate pressure on individual jurisdictions to lower domestic regulatory standards below what they would otherwise have been. This can be viewed as an externalities problem (...) The analysis of regulatory competition focuses on the challenges posed by the increasing mobility of economic actors in a global economy for the maintenance of domestic regulatory standards (...) The basic concern is that states will face pressure to lower their regulatory standards in order to attract or retain investment and employment within their borders. Examples include lowering of tax rates, labor standards, and environmental standards. This problem has been a common topic in discussions of regulation of economic activity in federal states, such as the United States. More recently, it has become a key subject in European integration. (...) There is a substantial academic debate as to whether international regulatory competition is always a "race to the bottom" If we consider the foregoing from a broader perspective, the question arises whether this kind of competition bxxetween legal systems may ultimately be at the expense of the level of protection of human rights and the protection of weaker parties in the EU. In the context of the project for which this contribution has been written and in which the OMC " method is the key element, the question also arises whether there is any risk, viewed from the perspective of the protection of human rights and the interests of "weak" parties, that States may "learn" from one another in a negative manner in this process. I.C. 'Risks of Unregulated Competition' - Need for a Central Regulator? - The Role of European Institutions or the European Member States. The foregoing justifies the following conclusion: on the one hand, national PIL provisions have traditionally played a regulatory role; on the other hand, liberal PIL rules at national level may be at the root of specific "risks" occurring in a situation of globalization. Naturally, this observation raises the question whether it is desirable to create a "central regulator" able to put a check on these "risks". M. Watt has formulated it as follows in her Guest Editorial: "Indeed, inter-jurisdictional mobility of firms, products and services is once again the means by which law is made to appear as offering on a competitive market, designed in turn to stimulate legislative reactivity and creativity". After first having issued the following warning: "Indeed, one of the most important issues raised by globalization from a private international law perspective is the extent to which private economic actors are now achieving "lift-off" from the sway of territorial legal systems. To some extent, traditional rules on jurisdiction, choice of law 
and recognition/enforcement of judgments and arbitral awards have favored the undermining of law's (geographical) empire, which is already threatened by the increasing transparency of national barriers to cross-border trade and investment. Party mobility through choice of law and forum indices a worldwide supply and demand for legal products. When such a market is unregulated, the consequences of such legislative competition may be disastrous."

As illustrated in the global context, one of the market failures to be feared in the context of unregulated competition is the exporting of costs or externalities linked to legislative choices of which the consequences may affect other communities. However, in an integrated legal system, these risks are restricted by the existence of a central regulator, armed with tools such as approximation of substantive rules, or, where diversity is deemed to be desirable, constitutional instruments designed to discipline the various States in their mutual dealings." The central theme of M.Watt's contribution is the possibility that one or both parties may take the initiative to use PIL rules for the purpose of escaping the sway of national provisions that nevertheless offer more protection in the area of fundamental rights and the pursuance of legitimate considerations - such as ensuring proper terms and conditions of employment for employees, combating environmental pollution etc. It is suggested in this context that if these attempts at avoiding national law are allowed without any restrictions, this may lead to regression and possibly even overall decline. For example, Muir Watt clearly makes her point that, when viewed from this perspective, there is a need for a regulatory supranational institution. But she does not point out how or where to find this supranational institution. However, Muir Watt draws attention to the "Posted Workers Directive" and Article 7 of the new Rome II Regulation concerning environmental pollution, but she does not present these as specifically "European" initiatives.

M. Watt left open in her Guest Editorial but what is highly significant in the context of the Refgov project for which this contribution has been written is the role to be played by the European legislator as "central regulator": Muir Watt does not deal - at least not explicitly - with the question whether "Europe" could be a suitable regulator or whether it would be better - also for the purpose of adhering to the subsidiary principle - to entrust this regulatory responsibility, where necessary, to the Member States themselves (it is needed to see the discussions in this context at the time of the preparation of the Rome III Regulation. As for the Netherlands's view on the adherence to the subsidiary principle, it is written by the Speakers of both Houses of Parliament (30 671 session year 2006-2007), available at http://europapoort.eerstekamer.nl. As for the European Commission's reaction to that it is needed to see:

http://www.cosac.eu/en/info/earlywarning/doc/comments_commission). She merely states as a follow-up to the above quotation relating to the European Court of Justice: "Here, as recent conflicts of laws implicating both economic freedoms and worker's rights have shown, the Court of Justice is invested with an important balancing function which clearly overflows into the political sphere", and in a footnote she refers to the Viking and Laval decisions, which I will address below. In this quotation, Muir Watt rightly points to the political aspect of the balancing process - which I will address below as well. In my analysis I will consider the question to what extent the European institutions - both the Court of Justice and the European legislator - are equal to the task of reducing the "risks" caused by liberal PIL rules to a minimum. I will also consider the question whether it is possible - or indeed, a fact in some cases - that the European institutions themselves are responsible for the "risks". To put it even more sharply: do European institutions act mainly as "guardian angel", or rather as "culprit"?

Should PIL be Regulated at European Level and, if so, How? Naturally, in areas where the European institutions regulate PIL, not only "national" but also "European" policy objectives will play a role. First and foremost, this includes considerations concerning the encouragement of the internal market, the creation of an area of freedom, security and justice, the promotion of European fundamental freedoms, adherence to the non-discrimination principle.

Even if it is not true that Dutch international family law has "lost its innocence" in current developments, as stated in the second chapter, this is certainly true for PIL in the European context: in the legal literature, the "lost innocence" of PIL was hinted at before in the light of the growing impact of state interests on PIL, particularly in an integrating Europe within which PIL functions as a legal policy instrument (M. Wat in the Choice of Law in Integrated and Interconnected Markets - a Matter of Political Economy 2003, Vol. 7.3) From the perspective of the legal protection of "weak parties" and the perspective of human rights promotion within the EU, the question may arise whether this loss of innocence is a good or a bad thing: Do these forces affecting PIL, which are also of European origin, have any adverse effects on the legal protection of weak parties? Is PIL in the process of becoming an instrument that creates race to the bottom dynamics or is it functioning as a catalyst for more far-reaching legal protection? To what extent is PIL under pressure from concerns about European objectives; to what extent does this give rise to frictions with the PIL of the respective EU Member States; to what extent do the European institutions press ahead with the idea of regulating PIL at European level, and what are the effects of these dynamics when viewed from the perspective of "human rights promotion within the EU"? Below, I will explore a selective number of "case studies" from this perspective. 
Specific international labour law aspects had already been regulated at European level even before the Amsterdam Treaty amended the EC Treaty and assigned PIL powers to the European institutions themselves. The Rome Convention on the law applicable to contractual obligations, opened for signature in Rome on 19 June 1980. The EEX Convention, which has by now been converted into a regulation, contains - if formally applicable - procedural PIL rules: rules concerning jurisdiction on the one hand, and recognition and enforcement on the other. The Rome Convention 1980 included applicable law rules that are applied by the contracting European Member States if a court in one of these Member States faces the question of what law is to be applied to an international employment relationship. The Rome Convention has existed for a long time now, but only in the near future will this PIL source become a European PIL source in the "true sense" of the word: the Rome Convention 1980 is to be converted into a regulation, known as the "Rome I" Regulation (Regulation (EC) No 593/2008 of the European Parliament and of the Council of 17 June 2008 on the law applicable to contractual obligations) This Regulation will not include fundamental changes in the field of PIL rules relating to employment relationships. For example, Rome I continues to adhere to the basic principle that PIL should regard the employee as the weaker party that should be protected in the context of the adoption of applicable law rules see also clause 23 of the Preamble of the Rome I Regulation, which reads as follows: "As regards contracts concluded with parties regarded as being weaker, those parties should be protected by conflict-of-law rules that are more favorable to their interests than the general rules", which, as far as contracts of employment are concerned, finds expression in the rule provided for in Article 8 of the Rome I Regulation. Accordingly, there is no room for controversies, is there? Nevertheless, if we consider the European PIL rules concerning contracts of employment a little more thoroughly and in broader terms, it is certainly possible to make some relevant observations and to identify remarkable dynamics and areas of tension from the perspective of the project for which this contribution is written.

PIL, Free Movement of Persons and Non-Discrimination: PIL as Achilles Heel of the Protection of Mobile Workers in Europe? Let us depart from one of the great European basic principles, particularly Article 39 of the EC Treaty (previously Article 49 of the EC Treaty). The first paragraph of Article 39 of the EC Treaty enshrines the principle of the free movement for workers, and the second paragraph includes the non-discrimination principle. Article 39 of the EC Treaty is certainly designed to further the economic objective of free movement for workers within Europe, but at the same time, it expresses a "social interest" * (inter alia, M. S. Houwerzijl, 2005, pp. 406-415; F. Hendrickx, 2007, issue 2, p. 43-83, particularly p. 55.) In the end, Article 39 of the EC Treaty confirms the right of the country of employment, and as such it is possible to pursue both the objective of the protection of equal treatment of workers within the territory where they reside, irrespective of whether they work on a permanent or temporary basis in the country of employment, and the objective of discouraging competition with respect to terms and conditions of employment. Competition with respect to terms and conditions of employment would not only be detrimental to a number of national social achievements, but it may also be contrary to the "proper" operation of the internal market, specifically fair competition. In this way, Article 39 of the EC Treaty ultimately succeeds in meeting both the interests of mobile workers and those of local workers and the interests of Member States in combating social dumping or unfair competition. Thus, Article 39 of the EC Treaty succeeds in striking a balance between social and economic interests. "Translated" into PIL, Article 39 of the EC Treaty would result in adherence to the country of employment principle in PIL. And this is what actually happens in Article 6 of the Rome Convention 1980. In the respective EU Member States, various labour law systems are applicable, but if an international labour law dispute is submitted to a court in one of the Member States, this court will usually apply the law of the country where the employee habitually carries out his work pursuant to Article 6 of the Rome Convention 1980. In PIL technical terms, this is based on the "protection principle" as recognized by PIL: the law with which the employee, being the weaker party, is assumed to be the most familiar is declared applicable.

But on closer consideration, the rule based on the country of employment principle, as enshrined in Article 6, is not applied unconditionally after all. This is because the country of employment principle is not an absolute principle in Article 6 of the Rome Convention 1980, if the full text of the Article is considered. As a result of choice of law options and the special rules included in Article 6 of the Rome Convention 1980, it sometimes happens that only the mandatory provisions of the country of employment are applied, and sometimes no provisions of the country of employment are applicable at all. For example, it may be that as a result of the application of PIL rules, an EU employee who works in another EU country is subject to terms and conditions of employment inferior to those applicable to local employees. In this way mobile EU employees may have less protection than local employees, and there is still a risk of social dumping after all. This is why in the legal literature PIL was labeled "the Achilles heel of the Community discrimination prohibition, which forms the cornerstone of the free movement of workers" (Article 6 (1) of the Rome Convention 1980, as well as Article 6(2), the b-situation and the "unless" provision, as well as the special scheme in Article 6(2) under (a) for employees who habitually work in a country but who are "temporarily" employed in another country (as for the exact 
meaning of the concept of "temporariness", see also Recital 36 of the Preamble to the Rome I Regulation). It turns out possible to escape the prohibition against discrimination based on nationality indirectly through PIL rules. If "social dumping" is to be avoided, a specific interpretation of the rules of Article 6 of the Rome Convention 1980 may be what is needed. Sometimes Article 7 of the Rome Convention - which includes the tenet of the "mandatory rules" - may also be invoked for the purpose of having specific "host country" rules declared applicable. It also turns out those national interests that reflect "protectionism" may also be presented as "humanitarian" interests, particularly if the national interest is presented as an interest of the mobile employee.

In international posting situations, however, it has been found that the application of Article 7 of the Rome Convention 1980 may be contrary to another European freedom, particularly, the free movement of services. The judgment rendered by the Court of Justice in the Rush Portuguesa (C-113/89, 27 March 1990) case and later decisions along similar lines constituted the basis for the foregoing. In this case, the parties involved - Portuguese employees of a Portuguese undertaking that wanted to provide services in France - could not invoke the free movement of persons and the related non-discrimination principle for the purpose of setting aside a French provision relating to required work permits: Under the transitional scheme applicable at the time, Portuguese employees could not exercise the right to the free movement of persons yet. The Court found a solution, however, by invoking the free movement of services and stating that the French requirement constituted an unjustified infringement of the Portuguese undertaking's right to the free movement of services. Later court decisions revealed a varied range of casuistic reasoning, in which the Court invariably had to address the question whether or not the host country's imposition of local terms and conditions of employment constituted a justified infringement of the right to the free movement of services vested in a foreign European undertaking that posted employees abroad.

And this is how the imposition of the host country's labour law rules - which may be regarded as the application of the country of employment principle, which in itself reflects the free movement of persons - was challenged by the foreign service provider as being "disruptive" of the exercise of the free movement of services (Cf. Hendrickx note 9 and the reference to the commission report, which also points out this "disruptive" factor of national labour law).

In the ECJ Arblade (1999 cases C-369/96 and 376/96, nos. 34 and 36) case, the Court ruled that the "freedom to provide services may be restricted only by rules justified by overriding requirements related to the public" but that "the overriding reasons related to the public interest which have been acknowledged by the court include the protection of workers (...)". Even so, the Court had to strike a balance and the legal literature points to the "danger" of the role assigned to the Court of Justice in this way, particularly the danger that in balancing the free movement of services against the protection of mobile workers, the Court may give priority to the former interest. For example, Hendrickx (p. 14) in footnote 40 , where he had written that the Court must strike a balance, but he went on as follows There is a real danger that the Court may develop an ever broader interpretation of unauthorized obstacles. In this context, the Member States "restrictive employment law provisions may also be regarded as barriers to the internal market".

Incidentally, the question whether or not PIL rules should be applied was addressed in a pregnant manner in cases brought before the Court of Justice, where the Court faced the question to what extent a national government is free to apply PIL rules in multiple nationality situations - both in family law issues and non-family law issues. This case law shows that through the "switch" of interaction with multiple nationalities, a case can be put on a specific track, which may affect the outcome of the case to a considerable extent; the manner in which Europe has "directed" and "channeled" these cases and its future position in this field are therefore crucial. European Interference in the Regulation of PIL in Interaction with the Unification of Substantive Law, Particularly, International Contract Law Questions concerning PIL in interaction with other branches of law have arisen in the discipline of international contract law as well. In recent years, Europe has been working on the unification of international contract law - by means of the conversion of the Rome Convention 1980 (the European Convention on the Law Applicable to Contractual Obligations) into the "Rome I" Regulation - as well as the unification of substantive contract law - by means of the project of creating a European Civil Code. As for both dynamics, inter alia, the publication by A. Fiorini, "The Codification of Private International Law in Europe: could the Community learn from the experience of Mixed Jurisdictions?", available at www.ejcl.org, on May 2008 in which he also stated the following on the subject of the Common Frame of Reference: "Once the material harmonization process is complete, there could perhaps be a case for the suppression of private international law within Europe: the material rapprochement would be such that the remaining differences, if any, would be easy to accept on the basis of a full faith and credit type clause"). Also the Green Paper on the conversion of the Rome Convention of 1980 on the law applicable to contractual obligations into a Community instrument and its modernization COM (2002) 654 final, under 1.6.

The applicable to contractual obligations into a Community instrument and its modernization COM (2002) 654 final, 
I briefly commented on the unification and harmonization of substantive law as a result of the creation of a "Common Frame of Reference" or an "Optional instrument". The conversion of the Rome Convention 1980 into a regulation has by now been completed, whilst the project to create a European Civil Code is still in full swing (Regulation (EC) No 593/2008 of the European Parliament and of the Council of 17 June 2008 on the law applicable to contractual obligations (Rome I) OJ L177/6, 4.7.200).

This latter project is progressing steadily, but even so, there are many question marks. I will confine myself to some remarks about discussions the project has sparked off in terms of fear of "social dumping" - a situation of reduced protection. This is because even though the creation of a European Civil Code apparently intends to offer parties an additional system of civil law only, which will not replace national legal systems - accordingly, the provisions designed to protect weaker parties incorporated into national legal systems could remain effective as such - it is still feared, insofar as the ECC for which parties may choose offers hardly any protection to the "weaker party" in the contract, that the level of protection for the weaker party will decrease if parties "choose" this ECC. It is remarkable that in the final version of the Rome I Regulation (contrary to the Proposal for the Regulation), no explicit reference is made to this kind of choice of law option (Recitals 13 and 14 of the Preamble to Rome I.). If reference is made to a "weaker party", this means the consumer first of all. A topic for discussion is the extent to which not only consumers but also medium-sized undertakings should enjoy protection. Traditionally, PIL considers not only the consumer but also the employee to be a structurally weaker party. Labour law was excluded from the scope of application of the Communication from the Commission on European Contract Law of 11 July 2001 (see COM (2001) 398 def, no. 14). The above discussions do not concern the substance of labour law as such, but it is certainly conceivable that there are parallel labour law issues, because PIL considers consumers as well as employees structurally weaker parties, for example, and the theme of consumer protection is relevant to the discussion. As far as labour law is concerned, it is worth mentioning the European Labour Law Network, which was set up recently. See the information to be found at www.elln.eu. The main activity of this initiative (particularly: "The development of general rules and principles of European labour law - on the basis of law studies in the different EU Member States - by using a restatement approach (...)", according to the website) is modest if it viewed from the perspective of unification of law trends, but this initiative may stimulate other developments, which will make PIL relevant in this context as well. Viewed from the PIL perspective, questions arise about the applicability of mandatory rules and provisions of the "normally" applicable law if the ECC is applicable pursuant to a choice of law that has been made. It is feared that "social dumping" would occur if, on the one hand, PIL provisions in respect of mandatory rules or provisions were no longer applicable, while, on the other hand, the ECC itself included insufficient protective provisions, for example, if it created a protection level that incorporated only the weakest protection level now existing in the Member States (J. Rutgers in An Optional Instrument and Social Dumping ERCL 2006, pp.199-212 et. al). In this respect, the relationship between the ECC and provisions from the Rome Convention 1980 or the Rome I Regulation has not crystallized as yet. As a matter of fact, the problem of the applicability of unified substantive law in international relationships, partly in relation to the Rome Convention 1980, emerged in the past in the context of the analysis of the applicability of European directives in the field of consumer law: in areas where the European legislator was already active in the field of consumer law by issuing directives, these directives usually include a PIL provision, although the PIL provision is usually unclear (S. Francq, 2005) Legal commentators have already complained that quite often this process paradoxically results in a larger diversity of conflict-of-law rules in the Member States rather than the intended harmonization of conflict-of-law rules and that as a result of Community interference, the unification achieved by the Rome Convention 1980 is being eroded (J. Meeusen, 1999-2000, pp. 434-435, with a reference to the contribution by D. Martiny, in ZeuP 1997, the title of which already referred to "erosion". In this context, see also, inter alia, Recital 40 of the Preamble to the Rome I Regulation, as well as the "Review clause" as included in Article 27(1) (b) of Rome I)

For the purposes of this contribution, the question arises whether this "erosion" is limited to the unification process and/or whether current developments especially erode the level of protection for weaker parties. In terms of the achievement of the ECC project: could the ECC be at the expense of the body of PIL in the field of protection of the weaker party? Certainly if a choice of law is made in favor of a non-European legal system, questions arise about the protection of the weaker party in terms of the manner in which PIL rules interact with unified rules of substantive law. The Ingmar judgment showed this as well. In the ECJ, Ingmar ( 2000, case C-381/98, NJ 2005/332, footnote by T. M. de Boer and Rechtskundig Weekblad 2001-2002, pp. 756-757, footnote by J. Meeuse) the Court of Justice faced the question of the applicability of a European directive that did not include any PIL rules, in a situation in which American law had been chosen. The Ingmar judgment concerns the legal position of the commercial agent, but in the legal literature, it is usually considered from the perspective of the legal protection of employees (A.A.H. van Hoek 2003, pp. 365-379). In its judgment, the Court holds that Articles 17 and 18 of the Agency Directive (86/653/EEC of 18 December 1986) under 
which the agent has specific rights after the termination of the agency contract, must be applied if the agent has performed his activities in a Member State, while the principal is established in a third country and the contract is governed by the law of this country in accordance with a clause included in it. The articles of the Agency Directive override the law of a non-European country chosen by the parties: in this case, the private law harmonized in a directive prevailed over the law designated by a conflict-of-law rule, which was in favor of the commercial agent, "the weaker party" in this case. Legal scholars face a tough job when it comes to interpreting the meaning of the judgment for the analysis of the relationship between harmonized private law in European directives and PIL. In general, the increases in the number of rules included in sectoral instruments that affect applicable law raise questions about the relationship with classical PIL rules. In the "Green Paper on the Conversion of the Rome Convention of 1980", it was proposed, as one of the possible solutions to the "problem", to include a provision in Rome I designed to safeguard the application of the Community minimum standard if all or some elements of the contract are connected with the Community (Green Paper on the Conversion of the Convention of Rome of 1980, under 3.1.2. $92 \mathrm{H}$. Muir-Watt in her contribution to the European Journal of Comparative Law, text and in footnotes 34 and 35).

In the final version of the Rome I Regulation, Article 3(4) provides as follows: "Where all other elements relevant to the situation at the time of the choice are located in one or more Member States, the parties" choice of applicable law other than that of a Member State shall not prejudice the application of provisions of Community Law, where appropriate as implemented in the Member States of the forum, which cannot be derogated from by agreement." This could ensure a "European minimum". The foregoing may be linked to an observation made by Muir Watt, where she refers to "requirements of collective welfare within the internal market", and deals with the regulation by a central authority by means of "harmonized substantive rules" and points out the following: "Whereas they take the form of minimum standards for internal market transactions, they are also projected into the world market in the form of internationally mandatory rules in cases where the European legislator has decided that the connection with the Community is sufficient to justify its interest. In both instances, they are designed to provide effective regulatory frameworks within which party choice can operate effectively." This, too, shows to what extent PIL rules can be decisive in ensuring "welfare", both in an intraCommunity European context and in a broader perspective.

\section{Conclusion}

In this contribution, I analysed the subject matter in an exploratory fashion. I have tried to show where and how regulation of PIL can "make a difference" when it comes to promoting human rights in Europe. This difference may sometimes arise in a rather veiled and indirect manner, but the consequences are usually far-reaching. Regulation of PIL is definitely relevant in one way or another. With respect to the regulation of PIL, both the possibilities and limitations associated with regulation at national level and the possibilities and limitations of supranational regulation by the European institutions should be taken into consideration. It turns out that the European legislator and the Court of Justice may fulfill their task of regulating PIL in different ways. The question whether PIL should be regulated at European level, and if so, how, has a variety of answers, depending on the subject matter and the interests involved, but it is definitely advisable to be aware of the dynamics and tensions in this area.

It turns out that regulation of PIL at European level sometimes allows the extrapolation - at European level - of the national PIL system that provides most human rights guarantees and/or protects weaker parties in the best manner. For example, a victim of international environmental pollution enjoys a higher level of protection at European level than at the Dutch national level. European-level regulation of PIL sometimes turns out to call a halt to social dumping mechanisms, for instance - see, for example, the effect of the Posted Workers Directive. Viewed from this perspective, the European legislator may be a guardian angel, a support and a "problem solver" of excesses that unregulated competition may give rise to. But European-level regulation of PIL may also show the dark side of the picture; it may even function as an evil genius and lie at the root of the problem. In particular, interference by European institutions may involve the risk of creating a "race-to-the-bottom" mechanism and kick-starting a process of liberalization that may dismantle national protection and defense mechanisms. Besides, to the extent that the European regulation of PIL disputes involving a "weaker party" is affected at the level of the "lowest common denominator" of the Member States, there is a risk that the weaker party's position will decline rather than improve.

Hence, a European "regulator" with "two faces", a Janus face as it were. The possibilities of promoting human rights that European-level regulation of PIL offers are promising. But when viewed from the perspective of the protection of human rights and weak parties, there are also risks. In this context, I distinguish two different types of risks in particular, connected with the dynamics of current European-level regulation of PIL. First, there is the risk, as mentioned 
above, that European interference might give rise to "excesses". In that case, the process of Europeanization may cause the Member States to "learn from one another" in a negative manner. National-level achievements in specific Member States might then have to be given up: lifting regulation to European rather than national level may mean that priorities other than national priorities will crystallize. In addition, there is a risk that national-level rules developed in specific Member States, which, essentially, should not be considered worthy of imitation, are extrapolated to the European level in this hypothesis, the European legislator would "learn" from regulation at national level in a negative way, in particular, through the extrapolation of national procedures to the European level. By analogy, reference may be made to developments in European migration law, where there are attempts to extrapolate restrictive national residence regulations of a questionable standard to the European level.

Then there is the risk of a division in the PIL of the Member States: insofar as European interference could be assessed positively, there is the risk that the Member States will not translate this positive development into their regulation of non-European cases. For example, I pointed out in the second chapter that the manner in which Dutch public authorities deal with PIL disputes involving third-country nationals weakens rather than strengthens the latter's legal position, whereas in a European context - as far as European citizens are concerned - international family law appears to be a driving force behind more rights. In this field, it appears that the dynamics may be in stark contrast with each other. The underlying political policy choices differ.

Many of the matters mentioned above involve legal policy choices 94 and some of these matters are hard to assess in terms of normative implications. The foregoing also shows that on the basis of the legal policy choice and the normative judgment made, PIL may sometimes be a suitable instrument for fighting a battle "with" PIL: attempts may be made to use PIL for legal policy objectives. In this contribution, I have illustrated at various points to what extent PIL may be used for the purposes of these legal policy objectives through technical-legal means, or to what extent a specific "choice" may be made or implemented by resolving PIL issues. Let me conclude by saying that by 2008 , the battle fought in the context of PIL is not only a battle for PIL- the very topical question which institutions are best equipped to regulate PIL issues - but also a battle in PIL - the ongoing debate on how PIL issues themselves may, or should be regulated substantively. Finally, in some areas, the fight against environmental pollution, social dumping, for example, and the discussions held in this context, there is also a battle with PIL. To conclude, I express the hope that in the future PIL will be used as a weapon in the battle against injustice and for enforcing a higher level of human rights protection.

\section{References}

A.A.H. van Hoek, „Het toepasselijk recht op arbeidsovereenkomsten - een reaktie op het Groenboek EVO", Sociaal recht 2003

A. Fiorini, „The Codificiation of Private International Law in Europe: could the Community learn from the experience of Mixed Jurisdictions?", available at www.ejcl.org, May 2008

F. Hendrickx, „Arbeidsrecht en vrij dienstenverkeer: een stand van zaken na de Dienstenrichtlijn", Arbeidsrechtelijke Actualiteiten 2007

H. Muir Watt, "Choice of Law in Integrated and Interconnected Markets - a Matter of Political Economy", EJCL 2003, Vol. 7/3

H. Muir Watt, "Choice of Law in Integrated and Interconnected Markets - a Matter of Political Economy", EJCL 2003, Vol. 7.3

$\mathrm{H}$. Verschueren, Internationale arbeidsmigratie. De toegang tot de arbeidsmarkt voor vreemdelingen naar Belgisch, internationaal en Europees gemeenschapsrecht, Brugge: Die Keure 1990

H. Heiss and N. Downes, „Non-Optional Elements in an Optional European Contract Law. Reflections from a Private International Law Perspective", ERPL 2005

J. Meeusen, "Instrumentalisation of Private International Law in the European Union: Towards European Conflicts Revolution?", European Journal of Migration and Law 2007, Volume 9, Number 3

J. Meeusen, "EVO, oneerlijke bedingen, verkoop op afstand, timesharing", in XXVIste post- universitaire cyclus Willy Delva, Overeenkomstenrecht 1999-2000, Gandaius, Kluwer

J. Rutgers, „An Optional Instrument and Social Dumping“, ERCL 2006

L. de Lima Pinheiro, „Competition between Legal Systems in the European Union and Private International Law" IPrax 2008,

M. S. Houwerzijl, „Bevordering van het EU-dienstenverkeer met behulp van gedetacheerde werknemers: tijd voor bezinning?" SMA 2005

R. Wai, „Transnational Liftoff and Juridical Touchdown: the Regulatory Function of Private International Law in an Era of Globalization", Columbia Journal of Transnational law 2002

S. Francq, L"applicabilité du droit communautaire dérivé au regard des méthodes du droit international privé, Brussels: Bruylant 2005. www.ejcl.org

http://europapoort.eerstekamer.nl.

http://www.cosac.eu/en/info/earlywarning/doc/comments_commission.

http://www.bundestag.de/bic/a_prot/2006/ap16054.html 